\title{
A new species of Boeckella (Copepoda: Calanoida) from arid Western Australia, an updated key, and aspects of claypan ecology
}

\author{
Kirsty Quinlan ${ }^{1 *}$ and Ian A.E. Bayly ${ }^{2}$ \\ ${ }^{1}$ Science and Conservation, Department of Biodiversity, Conservation and Attractions, Kensington, \\ Western Australia 6151, Australia. \\ 2501 Killiecrankie Rd, Killiecrankie, Flinders Island, Tasmania 7255, Australia. \\ * Corresponding author: kirsty.quinlan@dbca.wa.gov.au
}

\begin{abstract}
Boeckella pilkililli sp. nov. is described from a single, turbid, freshwater claypan located in the arid zone of Western Australia. The type locality is currently the only known location for the species. It was collected during an opportunistic survey of wetlands in the State's arid zone following a significant summer rainfall event in 2014. The most important diagnostic feature is located on the distal segment (B2) of the 2-segmented basipodite of the male fifth right leg where the distal inner edge is grossly transformed into a large, blunt, tongue-like outgrowth. As with other Boeckella inhabiting temporary wetlands, B. pilkililli sp. nov. is a relatively large species. A minireview of claypan ecology and a discussion of ecological aspects of body size and shape in Boeckella are included. An updated key to species of Boeckella occurring in the Australasian region is also presented. This incorporates three additional species.
\end{abstract}

KEYWORDS: Boeckella pilkililli, claypans, arid zone, wetlands, aquatic invertebrates, Australia, Zealandia

urn:Isid:zoobank.org:pub:F3179FE4-A9A6-43CC-8A38-DF6FC2394FC0

\section{INTRODUCTION}

Twenty species of Boeckella from Australasia (Australia and Zealandia) were recognised in Bayly's (1992) comprehensive work on the non-marine Centropagidae. The only additions to this have been Boeckella spinogibba Defaye, a species endemic to New Caledonia (Defaye, 1998), and Boeckella timmsi Bayly recorded from a shallow turbid claypan in Queensland (Bayly 1998). The recent discovery of the new species described below from a single shallow, turbid, freshwater claypan in Western Australia (WA) brings the total number of species now known from this region to 23, with 53 now known worldwide.

In Australia, many wetlands (including claypans) are ephemeral in nature, and those in more arid areas may fill only after significant, episodic rainfall events and then hold water for only a few weeks to a few months (Hancock and Timms 2002). Such unpredictable filling, combined with difficult access to many of these wetlands after rain, constrains surveying for aquatic invertebrate fauna in the arid zone. Consequently, the aquatic fauna has been documented from only a small number of arid zone claypans during biological surveys of the southern Carnarvon Basin, Wheatbelt, Pilbara, and Goldfields regions of WA (Halse et al. 2000; Pinder et al. 2004; Pinder et al. 2010; Quinlan et al. 2016) and of the Paroo region in New South Wales and southwestern Queensland (e.g. Hancock and Timms 2002; Timms and Boulton 2001) in eastern Australia. Many of these arid zone claypans are turbid, caused by the suspension of fine sediments, and typically have a 'muddy' appearance. While species richness is often lower in these turbid pans than other wetland types, they can comprise a unique fauna (e.g. Hancock and Timms 2002; Timms and Boulton 2001).

Specimens of the new Boeckella were collected in March 2014 during an opportunistic survey of a number of ephemeral wetlands (including two turbid claypans that had not been sampled previously) in WA's arid zone, following significant summer rainfall (Quinlan et al. 2016). The collection locality is within the Matuwa and Kurrara Kurrara Indigenous Protected Area (IPA), an area jointly managed by Martu (Tarlka Matuwa Piarku Aboriginal Corporation) traditional owners and the State Government of Western Australia (via Department of Biodiversity, Conservation and Attractions; Figure 1).

A description of this new species follows and includes an update to Bayly's (1992) original key for Boeckella species occurring in the Australasian region. This key incorporates all three of the post-1992 species, B. spinogibba, B. timmsi and B. sp. nov. 


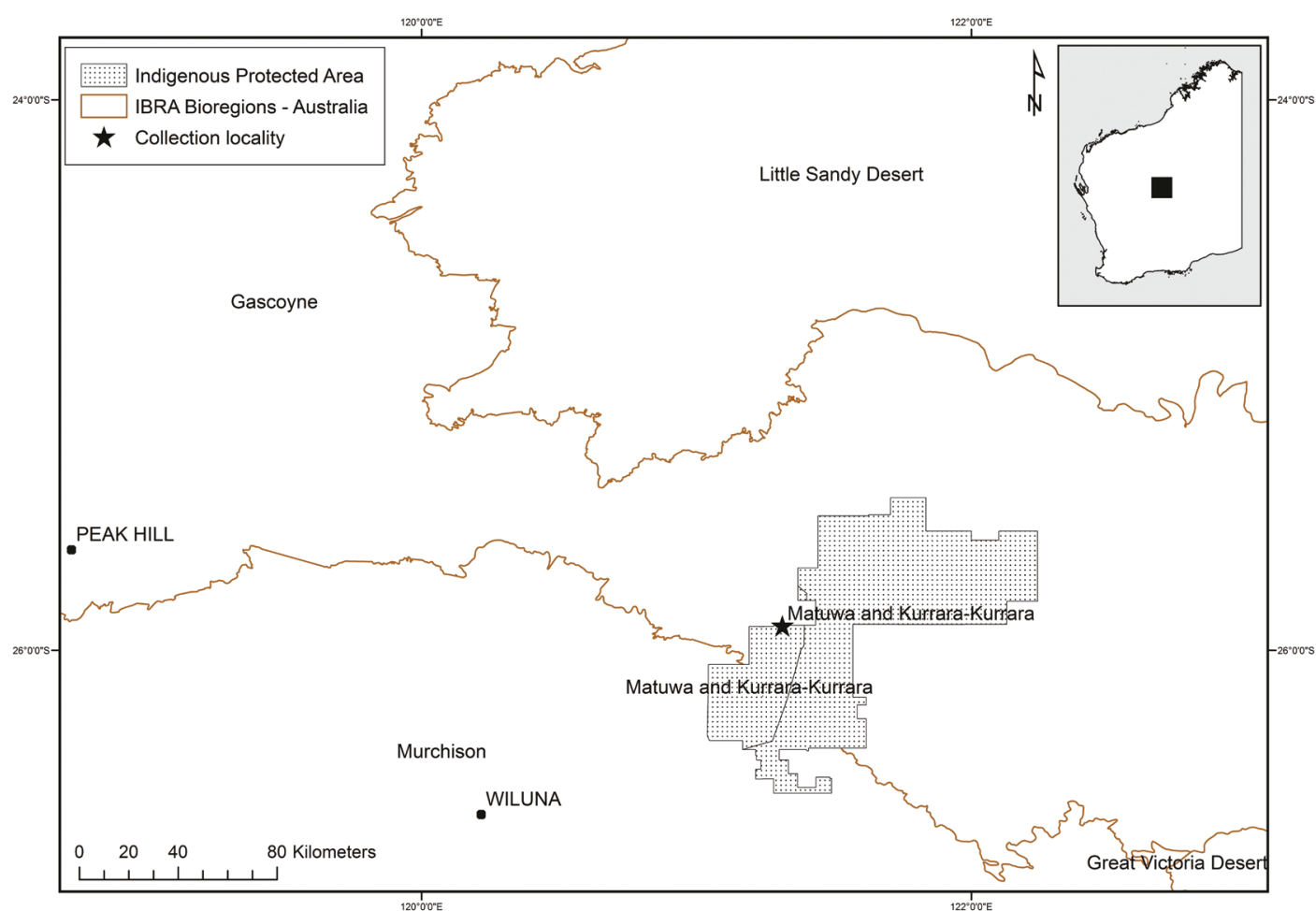

FIGURE 1 Map showing the collection locality for Boeckella pilkililli sp. nov. within the Matuwa and Kurrara Kurrara Indigenous Protected Area in Western Australia. Bioregions (IBRA7 http://www.environment.gov.au/land/nrs/ science/ibra\#ibra) are also illustrated.

\section{MATERIAL AND METHODS}

\section{FIELD METHODS}

Copepods were collected by two methods: a $50 \mathrm{~m}$ sweep of a plankton net (50 $\mu \mathrm{m}$ mesh) through open water only, and a $50 \mathrm{~m}$ sweep of a coarser net $(250 \mu \mathrm{m})$ through benthic sediments and open water. Samples were immediately preserved with $100 \%$ ethanol. Turbidity (NTU), electrical conductivity $\left(\mu \mathrm{S} \mathrm{cm}^{-1}\right)$, salinity $\left(\mathrm{g} \mathrm{L}^{-1}\right)$, water temperature $\left({ }^{\circ} \mathrm{C}\right)$ and $\mathrm{pH}$ were measured in-situ using hand held calibrated meters (TPS WP-81 and WP-88).

\section{LABORATORY PROCEDURES}

Calanoids were hand-picked from preserved samples, dissected and mounted on slides with polyvinyl lactophenol mountant. Whole specimens were measured using a Leica MZ16 stereomicroscope. Line drawings of several appendages (Figures $3 \mathrm{~A}-\mathrm{B}, 4 \mathrm{C}-\mathrm{D}$ ) were made by Jane McRae using a camera lucida attached to a Leica DM2500 differential interference compound microscope. A whole female specimen was drawn (J. McRae, figure 4B) using a camera lucida attached to a Leica MZ16 dissecting microscope. All scanning electron microscopy (SEM) work and images were undertaken by Dr. Russell Shiel. The specimens were prepared by dehydration through graded ethanol concentrations $(50 \%, 75 \%$ and $100 \%$ ), critical-point dried, transferred to an aluminium stub, and coated with carbon using a Quorum Q150TE carbon coater. Specimens were then examined with a Quanta 450FEG microscope. Material was deposited in the Western Australian Museum (WAM), Perth.

\section{SYSTEMATICS}

Subclass Copepoda H. Milne-Edwards, 1840

Order Calanoida Sars, 1903

Family Centropagidae Giesbrecht, 1893

Genus Boeckella De Guerne and Richard, 1889

\section{Boeckella pilkililli sp. nov.}

Figures $2 A-C, 3 A-D$ and $4 A-D$

urn:Isid:zoobank.org:act:5526EAF1-082C-44DF-87096B36171426DC

\section{MATERIAL EXAMINED}

\section{Holotype}

Australia: Western Australia: male, collected from a shallow, temporary, turbid, freshwater claypan situated within the Matuwa and Kurrara Kurrara Indigenous Protected Area (Figure 1), $150 \mathrm{~km}$ north-east of Wiluna (2554'40.6"S, 121 $\left.18^{\prime} 46.6^{\prime \prime E}\right)$. Collected by K Quinlan and J Futter, 17 March 2014 (WAM C70150, dissected on slide).

\section{Allotype}

Australia: Western Australia: female, collected by K Quinlan and J Futter, 17 March 2014 from the type locality (WAM C70151, dissected on slide). 


\section{Paratypes}

Australia: Western Australia: All specimens collected by K Quinlan and J Futter (17 March 2014) from the type locality. 1 male, (WAM C70152, dissected on slide); 1 female, unmounted whole animal in vial with $100 \%$ ethanol (WAM C70153); 3 males and 3 females, unmounted whole animals in vial with $100 \%$ ethanol (WAM C70154); 2 males mounted on aluminium stub for SEM images (WAM C70155).

\section{DIAGNOSIS}

This species is easily distinguishable from all other Boeckella by the large, blunt, tongue-like outgrowth observed on the inner edge of the B2 segment of the male fifth right leg. Of the species described to date, the new species shares some morphological affinity with Boeckella geniculata Bayly, which has a somewhat similar outgrowth on the right B2 segment, albeit with a markedly different shape. However, the new species differs from $B$. geniculata in many respects, including the lack of a pseudochelate right Re claw, in addition to differences in the structure and form of both the left and right Ri segments.

\section{DESCRIPTION}

In the following description we follow the terminology, conventions and abbreviations set out in Bayly (1992, figure 1) for legs 1-5. Alternative terms for our use of B1 and B2 are coxa and basis respectively and for $\mathrm{Re}$ and $\mathrm{Ri}$, alternative terms are exopodite and endopodite respectively. Additionally we use the symbol ' $\mathrm{X}$ ' to mean 'times' in the multiplication sense.

\section{Male}

Size: Length of prosome (measured along midline) ranges from $1.48-1.83 \mathrm{~mm}$ (mean $1.66 \mathrm{~mm}$; $\mathrm{n}=9$ ); length from front of prosome to end of caudal rami 2.30-2.67 mm (mean $2.47 \mathrm{~mm} ; \mathrm{n}=9$ ).

Antennule, antennae and buccal appendages shown in Figures 2A and 2B.

Antennule: Left antennule 25-segmented, as in female. Right antennule 22-segmented, hinged between segments 18 and 19.

Antennae: Re 7-segmented, terminating in 3 setae. Ri 2-segmented. Ri2 prolonged by a lobe, giving the appearance of a third segment, but with no complete suture line visible. Proximal segment with 8 setae and lobe with 6 long setae, 1 shorter, thinner seta, and a row of spinules on inner margin.

Labrum: rounded anterior edge, ornamented with a dense fringe of long hairs (Figure 2A).

Mandible: Masticatory edge with 8 teeth and 1 spinulose seta. Re of palp 4-segmented, Ri of palp 2 -segmented, proximal segment with 4 setae, terminal segment with 8 setae and a row of spinules on the inner margin.

Maxillule: External lobe bearing usual 9 plumose setae, internal lobe with $9+4$ spine-like setae; B1 endites with 4 setae. B2 with 5 marginal setae, Ri 2-segmented, separated from B2, with 4 setae on proximal segment and 5 on distal segment. Re unsegmented with 9 setae.

Maxilla: The first endite (proximal) bearing 3 long spinulated setae and 2 shorter setae. Endites $2-4$ bearing 2 long spinulated and 1 shorter setae. The fifth endite bears 2 long spinulated setae, 1 shorter seta and 1 large spine-like seta. Ri 3-segmented with setation pattern: 2 , $1,2$.

Maxilliped: B1 segment slightly shorter than B2, bearing a submarginal row of fine spinules along the distal margin of segment. B2 with a submarginal row of fine spinules along the proximal inner half and 3 setae along the distal inner half of this segment. Ri 5 -segmented, although full segmentation is difficult to distinguish.



FIGURE 2 Boeckella pilkililli sp. nov. scanned electron micrograph (SEM) images of male paratypes, mounted on an aluminium stub (WAM C70155): $A$, ventral view of the anterior end of prosome; B, anterior half of body, showing hinged antennule; $\mathrm{C}$, fifth leg (posterior aspect). Scale: $A \& C=0.3 \mathrm{~mm}, B=0.5 \mathrm{~mm}$. 

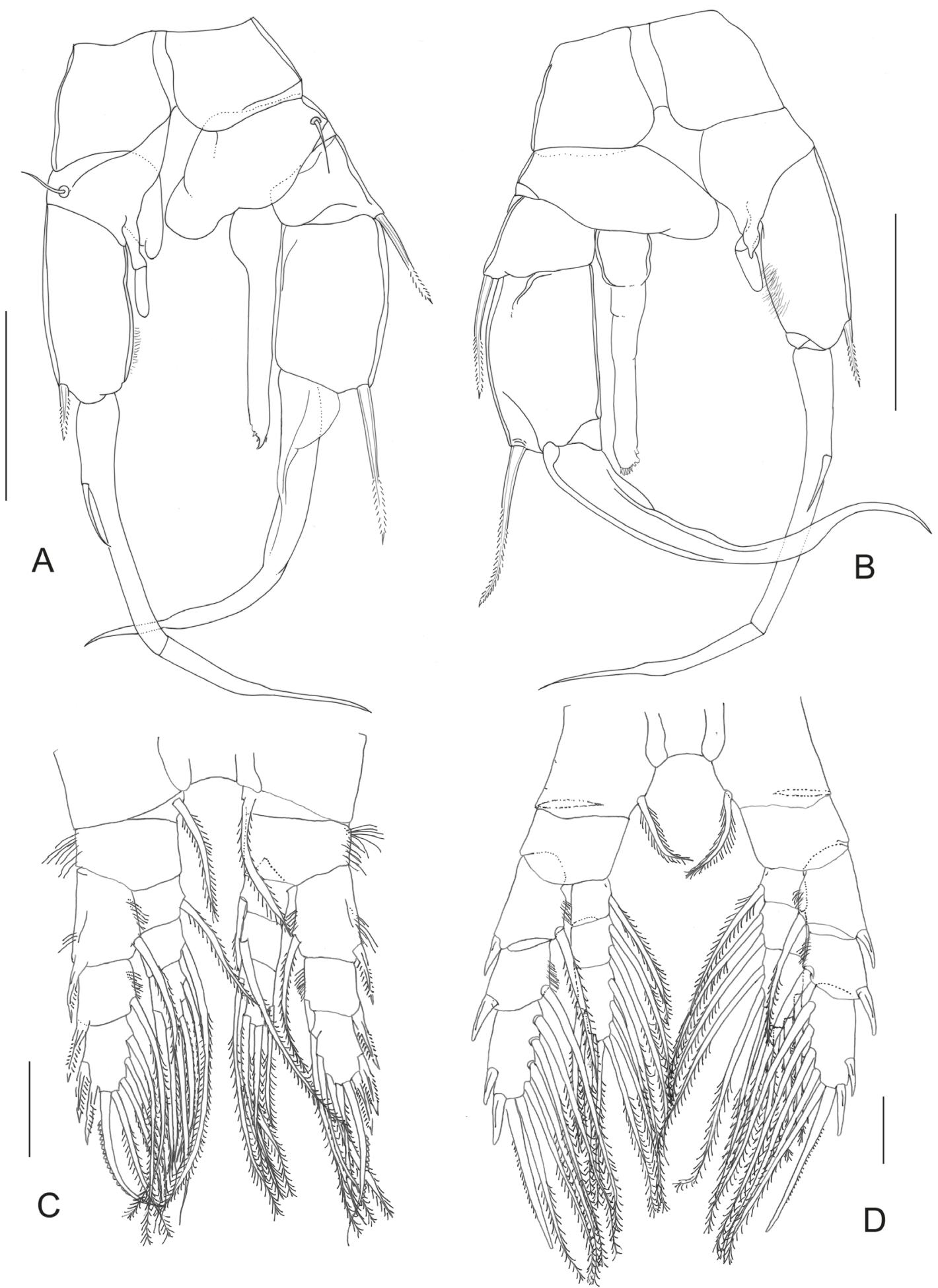

FIGURE 3 Boeckella pilkililli sp. nov.; A \& B, posterior and anterior aspects, respectively, of male fifth legs (WAM C70150 and WAM C70152); C, first pair of legs of male holotype (WAM C70150); D, fourth pair of legs of male holotype (WAM C70150). Scale: $A \& B=0.2 \mathrm{~mm}, C \& D=0.1 \mathrm{~mm}$. 
Urosome: Composed of 5 somites. Caudal rami symmetrical; each ending in five long terminal setae lined with fine hairs, and one shorter, thinner seta inserted on the inner distal corner. The setation pattern is same as female.

Legs 1-4: $\mathrm{Re}$ and $\mathrm{Ri}$ of legs 1-4 distinctly 3-segmented. Legs increasing in size from 1 through 4. Rel and Re2 of each leg bearing a robust spine at outer distal corner of segment. Re3 bearing two short outer spines, one longer terminal spine on distal edge, and five long setae (four in leg 1) along inner edge of segment (Figures 3C-D). The serrations along each of the spines on segments Rel-Re3 of leg 1 are longer and more robust, than the spine serrations on legs 2-4 (Figures 3C-D). Setae all bearing fine hairs. The formulae of spines and setae for legs 1-4 are as follows:

$$
\text { B1 B2 Re Ri }
$$

$\begin{array}{lllll}\text { leg } 1 & 0-1 & 0-0 & \text { I-1; I-1; II-I-4 } & 0-1 ; 0-1 ; 1-2-3 \\ \text { leg } 2 & 0-1 & 0-0 & \text { I-1; I-1; II-I-5 } & 0-1 ; 0-2 ; 2-2-4 \\ \text { leg } 3 & 0-1 & 0-0 & \text { I- } 1 ; \text { I-1; II-I-5 } & 0-1 ; 0-2 ; 2-2-4 \\ \text { leg } 4 & 0-1 & 0-0 & \text { I-1; I-1; II-I-5 } & 0-1 ; 0-2 ; 2-2-3\end{array}$

Fifth leg (Figures 2C, 3A-B): Inner edge of right B2 with large, blunt, tongue-like outgrowth extending inwards beyond median plane and almost to edge of left B2 segment. This is undoubtedly the most diagnostic character of this new species. Right $\mathrm{Ri}$ swollen near basal attachment, greatly elongated, reaching well beyond junction of right $\mathrm{Re} 2$ and Re3 (Re claw), 6X as long as maximum width near basal attachment, with distal extremity bearing small, curved, spine-like process and several minute serrations. Right Re2 bearing long spine at outer distal corner, with length of spine equal to length of segment bearing it. Left B2 segment with small lobe at inner distal corner. Left Ri 2-segmented with terminal segment (Ri2) digitate, extending c. half-way along inner edge of left Re1. Left Re claw 2-segmented with $\mathrm{Re} 2$ c. $1.2 \mathrm{X}$ longer than Re3. Outer spine inserted at $0.3 \mathrm{X}$ distance along $\mathrm{Re} 2$. Both left and right $\mathrm{Re}$ claws narrow abruptly before tapering to a point at the distal extremity.

\section{Female}

Size: Length of prosome (measured mid-dorsally to exclude large 'wing' structures on last prosomite) 1.69-1.98 mm (mean $1.86 \mathrm{~mm}$; $\mathrm{n}=8$ ); length from front of prosome to end of caudal rami $2.48-2.81 \mathrm{~mm}$ (mean $2.65 \mathrm{~mm} ; \mathrm{n}=8$ ). Prosome with pedigerous somites 1 and 2 and 4 and 5 separate. 'Wing' structures at the posterior lateral margin of last prosomite well developed and extend c. 0.8 of the way along genital compound somite (Figure 4B).

Antennule: 25-segmented. Aesthetascs on segments 1, 2, 3, 5, 7, 9, 11, 12, 14, 16, 19 and 25. Short spine present on segments 8 and 12 (Figure 4A). Antennule c. $1.8 \mathrm{~mm}$ in length, and when extended posteriorly reaching only as far as the posterior end of the prosome (Figure 4B). Antennae and buccal appendages as in male.

Urosome (Figure 4C): Genital compound somite c. $1.2 \mathrm{X}$ as long as maximum width. Free urosomites 2 and 3 approximately equal in width, but somite $31.3 \mathrm{X}$ length of somite 2. Caudal rami c. $2 \mathrm{X}$ as long as maximum width, each ending in five long terminal setae lined with fine hairs, and one shorter, thinner seta inserted on the inner distal corner, Caudal rami lined with hairs along innermost margins.

Legs 1-5: Re and $\mathrm{Ri}$ of legs 1-4 distinctly 3 -segmented. Formulae of spines and setae for legs 1-4 identical to those of male. Fifth leg of female similar in size to leg one, both of which are smaller than legs 2-4. Re1 of fifth leg with one outer spine, Re2 with one outer spine and the usual centropagid inner process, Re3 with two outer spines, one terminal spine and four inner setae (Figure 4D). Ril of fifth leg with fine hairs on outer edge and one plumose seta on inner edge, Ri2 with one inner plumose seta, Ri3 with 2 inner, 2 terminal and 2 outer plumose setae (Figure 4D).

\section{ETYMOLOGY}

The specific name 'pilkililli' is the word for claypans in the language of the southern Martu Aboriginal people (Tarlka Matuwa Piarku Aboriginal Corporation, 2015) and refers to the habitat type from which this species was collected; noun in apposition.

It was named in consultation with Elders from the Tarlka Matuwa Piarku Aboriginal Corporation, the traditional custodians of the Matuwa and Kurrara Kurrara Indigenous Protected Area, to acknowledge the land on which it was found.

\section{DISCUSSION}

\section{COMPARATIVE ASPECTS OF THE MALE FIFTH RIGHT BASIPODITE IN SPECIES SEPARATION}

In the male fifth pair of legs of Boeckella the right basipodite, which has 2 segments (B1 and B2), is typically of little importance among the secondary sexual structures that allow the separation of species. There are, however, exceptions. The South American (SA) species, B. bergi Richard, is the only species in which the B1 is sexually transformed by having a prominent projection at the inner distal corner. Modification of the right B2, however, occurs in a minority of species: 


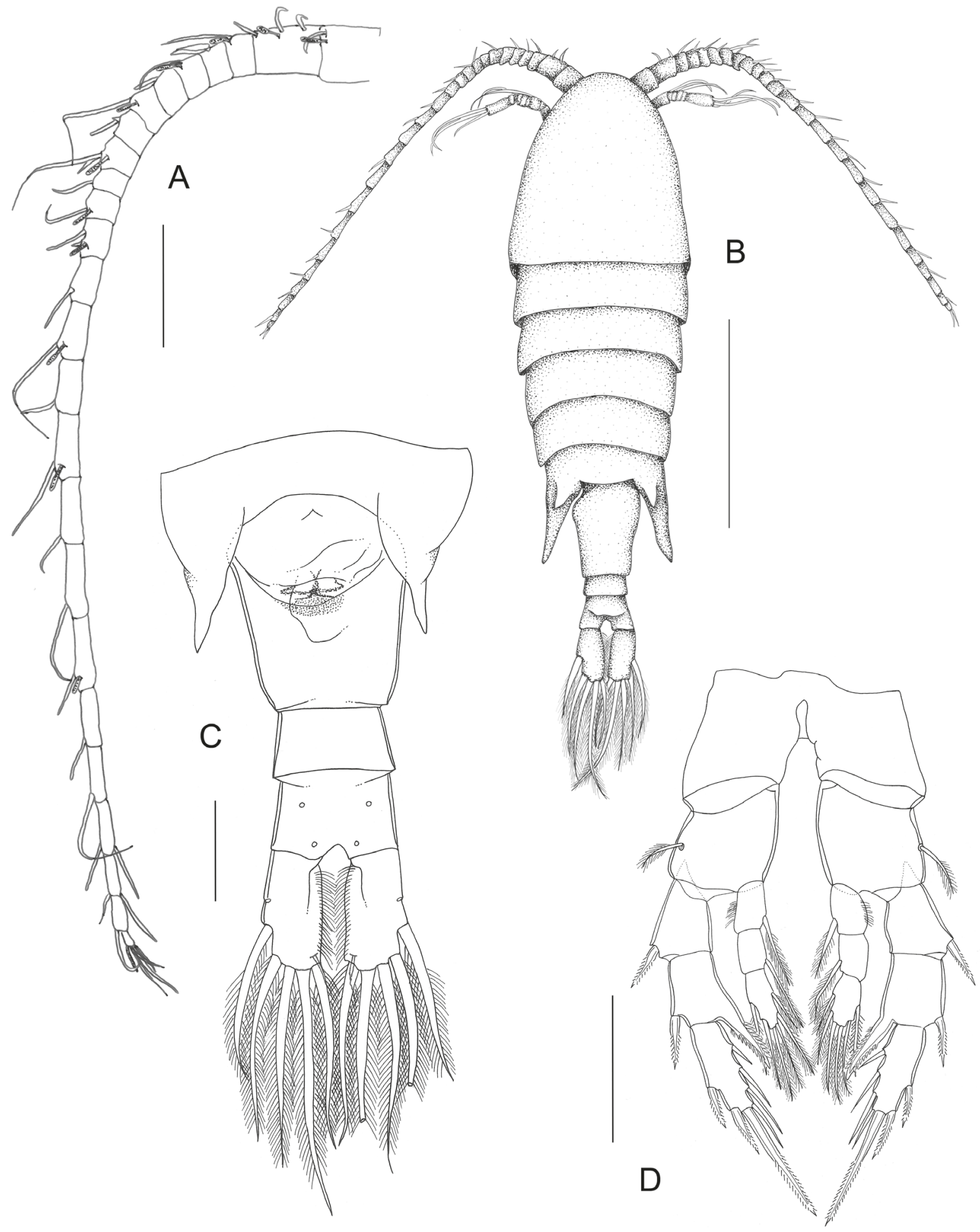

FIGURE 4 Boeckella pilkililli sp. nov.; A, Antennule of female allotype (WAM C70151); B, whole animal, dorsal view of female paratype (WAM C70153); C, ventral aspect of female urosome, including genital compound somite (WAM C70151). D, fifth pair of legs of female allotype (WAM C70151). Scale: A, C \& D = $0.2 \mathrm{~mm}, B=1 \mathrm{~mm}$. 
1. in B. rubra Smith it bears a prominent spine at the inner distal corner;

2. in B. geniculata it has a broad expansion along the whole of the inner edge;

3. in B.bispinosa Bayly, B.propinqua longisetosa Smith, B. bergi, B. meteoris Kiefer (SA) and $B$. poopoensis Marsh (SA) there is a blunt projection on the inner edge.

B. pilkililli sp. nov. approximates somewhat to $B$. geniculata and joins species in group (3) in a highly exaggerated manner. The inner edge of B2 is produced into a large, tongue-like expansion that crosses the median plane. In summary, B. pilkililli and B. geniculata possess the most highly transformed male fifth right B2 in the entire genus. However, B. pilkililli differs markedly from $B$. geniculata in that the right Re claw is not pseudochelate, and the right $\mathrm{Ri}$ is straight rather than possessing a geniculate bend.

\section{DISTRIBUTION}

Boeckella pilkililli sp. nov. is currently known only from its type locality; a characteristically shallow (< $40 \mathrm{~cm}$ deep), temporary, turbid (turbidity 319 NTU), freshwater (salinity $0.09 \mathrm{~g} \mathrm{~L}^{-1}$ ) claypan, which had a $\mathrm{pH}$ of 7.76 and a water temperature of $28.6{ }^{\circ} \mathrm{C}$ (Quinlan et al. 2016). The new species may be more widespread and associated with other turbid claypans within the Gascoyne and Murchison IBRA (Interim Biogeographic Regionalisation for Australia; Australian Government 2012) bioregions. However, additional survey opportunities to determine its distribution are limited in the short-term by the unpredictable nature of rainfall in the arid zone, the temporary nature of these pans and the difficulty in accessing them after episodic rains.

\section{ASPECTS OF AUSTRALIAN CLAYPAN ECOLOGY}

\section{General features and life-histories of calanoids}

Claypans are a distinctive aspect of the arid and semiarid regions of Australia, and famous nineteenth century explorer, Ernest Giles, was perhaps the first (Giles 1889, vol. 1, p.39) to give a good definition of one. The use of claypans as a source of fresh water by desert Aborigines was discussed by Bayly (1999).

Williams (1985), in his general classification of temporary standing waters, assigned claypans to a distinct type ('Type D') characterised by being discrete, unpredictably filled and having fresh water. Halse et al. (2000) studied a series of claypans in the southern Carnarvon Basin, Western Australia, and found that less turbid ones, and those where water levels were still high (pre-recession phase) had higher species richness. Hancock and Timms (2002) studied the ecology of four claypans in the Paroo region of semi-arid Australia and concluded that among the more important factors characterising these habitats were: shallowness, high turbidity, short filling phase, low conductivity, highly variable temperatures and lack of vegetation. This list, which also fits the habitat of Boeckella pilkililli sp. nov., contains several stress factors which would suggest that claypans should contain lower species richness or a more simplified community structure than deeper, more permanent, clear-water, vegetated, freshwater ponds or lakes. In the Paroo region, where Australian claypans have been best studied, this expectation is met, but not to the extent that one would expect. Timms (2002) makes two important statements on this issue: (1) 'Compared with other wetlands in the Paroo, claypans are one of the least speciose'; (2) 'Even so they are surprisingly rich considering the lack of vegetation and the homogeneous habitat.'

There are preliminary indications that flooded claypans may contain distinctive, specialist species. Paroo crustacean species characteristic of, or known only from, claypans (Timms 2002) include: Branchinella $5 \mathrm{spp}$, Ozestheria (formerly Caenestheria) 2 spp, Triops australiensis Spencer \& Hall, Daphnia projecta Hebert, Moina australiensis Sars, Latonopsis brehmi Petkovski, Calamoecia 3 spp, Boeckella robusta Sars and B. timmsi. The last mentioned species is currently known only from highly turbid claypans in the Currawinya National Park (Bayly 1998) and the Paroo region (Hancock and Timms 2002) where it appears fleetingly and very early in succession between 7 and 18 days after filling. $B$. pilkililli may approximate to a counterpart species in the western half of the Australian arid core.

The type locality filled after significant rainfall across the Gascoyne and Murchison bioregions in early and late January of 2014. Remote sensing data acquired from Landsat satellites 7 and 8 , indicated that the claypan held water from 28 January to 12 May 2014. Specimens of B. pilkililli were collected on 17 March 2014 about 6-7 weeks after filling near the middle of the hydroperiod. We do not know when this species first appeared in the wetland, or how long it persisted, but it evidently appears later in succession than $B$. timmsi. More is known about the life-history of some other temporary-water species of Boeckella. B. robusta robusta Sars is a short-lived (c. 15-30 days after filling) species in claypans in the Paroo region (Timms 2001). B. major Searle matures rapidly, typically within a few weeks after a wetland fills, produces resting eggs and then disappears (Green et al. 1999). B. pseudochelae Searle reaches maximum numbers later, more towards the middle of a pool's hydroperiod (Morton and Bayly 1977). At this stage more information is needed to determine the life-history of $B$. pilkililli. 


\section{Ecological aspects of body size in Boeckella}

Of the 22 known species of Boeckella in the Australasian region, B. robusta and B. major are two of the largest, with body lengths $>4 \mathrm{~mm}$ recorded, and Boeckella minuta Sars, with a male body length $<1.2$ $\mathrm{mm}$ (female $<1.57 \mathrm{~mm}$ ), one of the smallest (Bayly 1964, 1978; Green et al. 1999; Timms 1968). Of the remaining species, there is considerable overlap in the range of mean body size, owing largely to the differences in size between males and females (sexual dimorphism) and differences due to seasonal variation (Bayly 1964; Bayly 1978). Despite this variation, it is noted here that $B$. pilkililli is one of the larger species of the genus, with males ranging from $2.30-2.67 \mathrm{~mm}$ in length (to end of caudal rami; $\mathrm{n}=9$ ) and females $2.48-2.81 \mathrm{~mm}$ in length $(\mathrm{n}=8)$.

Given that body size can be quite variable, both within and between populations of a species, it has been suggested (Bayly 1978) that the actual ratio between the mean body size of males and females in a given population of a species, is a more reliable metric to use for comparison between species of Boeckella. According to Bayly (1978), the magnitude of sexual dimorphism is larger in some species (e.g. B. minuta, B. symmetrica Sars, B. opaqua Fairbridge and B. bispinosa), and less so in others (e.g. B. rubra, B. nyoraensis Searle and B. tanea Chapman). With such a small sample size, it is difficult to provide a statistically valid conclusion, however, for B. pilkililli, the ratio of female length:male length (from front of prosome to end of caudal rami) is 1.07 , and is therefore not considered to be highly dimorphic. This is also true for other large species such as B. robusta and $B$. major (Bayly 1978).

Distinct differences in body proportions exist between calanoid copepods which occupy a limnetic habitat and those that occupy a more littoral/pond habitat, as discussed in Timms (1979). To better understand the type of habitat perhaps utilised by $B$. pilkililli sp. nov, body proportions for this new species were quantified. Timms (1979) calculated ratios of metasomal length:metasomal width (ML:MW) and antennule length:metasomal length (AL:ML) to determine the variation in body build between species. His calculations of so called 'metasomal' (=prosomal) length and width are equivalent to prosomal length (PL) and prosomal width (PW). The ratio of PL:PW for males of $B$. pilkililli was $2.57 \pm 0.19 \mathrm{SD}(\mathrm{n}=9)$ and $2.62 \pm 0.18(\mathrm{n}=8)$ for females The AL:PL ratio was $1.04 \pm 0.08$ for males and $0.98 \pm 0.08$ for females. With only a limited sample size, a more statistically valid conclusion is difficult. However, these body proportions for $B$. pilkililli are intermediate between the ratios for littoral and limnetic copepods (2.1-2.3 and 3.0-3.4 respectively) given in Timms (1979). B. pilkililli is therefore considered to be of a medium build with short antennules, having a AL:PL ratio less than that of littoral species such as B. major (e.g. $<1.28$ ). These body proportions would suggest that B. pilkililli is unlikely to be limnetic in habit. If this hypothesis is correct, it may be important in sampling claypans to ensure collection from all habitats (benthic and limnetic) as was done in the present study. Traditionally, planktonologists try to avoid doing this because 'dirty' collections are difficult to examine.

Calamoecia halsei Bayly, another centropagid calanoid, co-existed with $B$. pilkililli at the type locality. It is also an ephemeral wetland specialist and was easily distinguished from the new species by the clear difference in size. Boeckella pilkililli is approximately two times larger, with a mean body length (to end of caudal rami) of $2.47 \mathrm{~mm}$ for males and $2.65 \mathrm{~mm}$ for females, whereas the mean body length of Calamoecia halsei was $1.10 \mathrm{~mm}$ for males $(\mathrm{n}=5)$ and $1.30 \mathrm{~mm}$ for females $(\mathrm{n}=5)$. The cooccurrence of calanoids is common in the genera Boeckella and Calamoecia in WA (e.g. Bayly 1982, 1985; Maly and Maly 1997; Maly et al. 1997; Quinlan et al. 2016; Storey et al. 1993; Williams 1979) and so too is size difference between species of co-occurring calanoids (e.g. Maly and Maly 1997; Halse and McRae 2001).

An updated key to the described Australasian species of Boeckella, based on characters of the male fifth leg, is provided below. As far as practicable, the key has remained true to Bayly's (1992) original dichotomous key. The first of three new additions ( $B$. pilkililli) enters the key at couplet 7. From there, the original key is altered, with $B$. timmsi appearing in the revised couplet 10 and $B$. spinogibba appearing in the revised couplet 18. B. spinogibba and the three species endemic to New Zealand (B. dilatata Sars, B. hamata Brehm and $B$. tanea) are denizens of the largely sunken continent of Zealandia with which they may be presumed to have had an ancient association (Bayly and Boxshall 2009; Mortimer et al. 2017).

\section{AN UPDATED KEY TO SPECIES OF BOECKELLA OCCURRING INTHE AUSTRALASIAN REGION (AUSTRALIA AND ZEALANDIA)}

(Key features refer to the male fifth leg unless otherwise stated. All figures in the key, with the exception of Figures 11, 13 and 21, are taken (with permission) from Bayly, 1992; pp. 11-19). 
1. Re3 of female fifth legs with 2 spines (Figure 5A) (For male fifth legs see Figure 5B). B. minuta Sars, 1896

Re3 of female fifth legs with more than 2 spines ..... 2

2. Right Re claw pseudochelate at extremity (see arrows in Figures 6-8) 3

Right Re claw not pseudochelate (tapering smoothly to single point) at extremity .5

3. Right Ri extending no more than halfway along inner edge of right Re2 (Figure 6). .. shieli Bayly, 1985

Right Ri extending to distal limit of right Re2 or beyond. 4

4. Right B2 extending inwards at least as far as median plane; right $\mathrm{Ri} 3$-segmented, without basal inner projection, distal quarter bent outwards through about 45 degrees (Figure 7). B. geniculata Bayly, 1964

Right B2 not extending inwards as far as median plane; right $\mathrm{Ri}$ extremely long but 1-segmented, with basal inner projection, distal quarter not bent outwards (Figure 8). B. pseudochelae Searle, 1912

5. Right B2 with prominent spine at inner distal corner, half as long as, and in addition to, right $\mathrm{Ri}$ (see arrow Figure 9). B. rubra Smith, 1909

Right B2 with no spine (but sometimes with blunt outgrowth) at inner distal corner in addition to right $\mathrm{Ri}$.

6. Right Ri with 2 or 3 spines at distal extremity (see arrow Figure 10). B. bispinosa Bayly, 1967

Right Ri either smoothly rounded, or with single spine-like process at distal extremity......

7. Right B2 with large, blunt, tongue-like outgrowth at inner distal corner, extending inward beyond median plane; right $\mathrm{Ri}$ elongate, extending beyond junction of right Re2 and Re3 (Figure 11). B. pilkililli sp. nov. (A large species endemic to Western Australia. Recorded from a shallow, turbid, freshwater claypan in the State's inland).

Right B2 lacking large, blunt, tongue-like outgrowth at inner distal corner. .. 8

8. Distance between right $\mathrm{B} 2$ and left $\mathrm{B} 2$ at level of their attachment to B1 greater than proximal width of either right or left B2 (see arrows Figure 12). B. dilatata Sars, 1904
Distance between right $\mathrm{B} 2$ and left $\mathrm{B} 2$ at level of their attachment to B1 less than proximal width of either right or left $\mathrm{B} 2$. ... 9

9. Right Ri with inner projection or sharp angle near proximal attachment to right B2 (see arrows Figure 13-17). 10

Right Ri lacking inner projection or sharp angle near proximal attachment to right $\mathrm{B} 2$. .14

10. Right Ri sub-triangular and 2- or 3-segmented, reaching less than half-way along inner edge of right Re2 (Figure 13). ......... B. timmsi Bayly, 1998 (A rare species, collected from a shallow, highly turbid freshwater claypan in Queensland) (Note: Figure 13 is after Bayly, 1998).

Right Ri not sub-triangular, typically 1-segmented and of variable length (Figures 14-17)..... 11

11. Left B2 with conspicuous teeth attached in vicinity of inner distal corner (see arrow or arrows in Figures 14-15). 12

Left B2 with no conspicuous teeth attached in vicinity of inner distal corner. 13

12. Left B2 with teeth in single row (see single arrow Figure 14) B. triarticulata Thomson, 1883

Left B2 with teeth in two rows (or apparently so) (see two arrows Figure 15)....... B. fluvialis Henry, 1922

13. Right Ri extending only c. half-way along right $\mathrm{Re} 2$, right $\mathrm{Re}$ claw with abrupt narrowing near distal extremity (see arrow Figure 16).

B. hamata Brehm, 1928

Right Ri extending to distal extremity of right Re2, right $\mathrm{Re}$ claw tapering evenly to distal extremity (Figure 17). B. robusta Sars, 1896

14. Left Rel long relative to right Re, distal extremity lying directly opposite distal extremity of right $\operatorname{Re} 2$ (see dotted lines at right angles in Figures 18-20).

Left Rel short relative to right Re, distal extremity lying directly opposite a point only $0.4-0.7$ times distance along inner edge of right $\operatorname{Re} 2$ (in nearly all cases it is the point of insertion of the outer spine of left Re2, instead of the extremity of left Re1, that lies opposite the extremity of right $\operatorname{Re} 2)$. 
15. Right $\mathrm{Ri}$ with $45^{\circ}$ bend ( $\mathrm{Ri} 3$ at angle of $45^{\circ}$ to long axis of Ril) (see arrow Figure 18); right Re claw not recurved, narrowing abruptly about $2 / 3$ length from distal extremity (see arrow Figure 18). B. nyoraensis Searle, 1912

Right Ri straight (typically distinctly or indistinctly 2- or 3-segmented); right Re claw recurved and tapering evenly to distal extremity..... .16

16. Left B2 produced at inner distal corner into pointed process bearing small spines along inner edge only, this segment with no upraised semicircular lobe on anterior aspect (Figure 19). B. delicata Percival, 1937

Left B2 produced at inner distal corner into pointed process bearing small spines on both inner and outer edges, this segment with upraised semi-circular lobe on anterior aspect immediately proximal to pointed process (Figure 20).

.B. montana Bayly, 1964

17. Right Ri 1-segmented and narrowing slightly towards distal extremity (Figures 21-23)............18

Right Ri 2- or 3-segmented (sometimes indistinct), with variable articulation. 20

18. Left $\mathrm{Ri}$ small, reduced to a triangular plate and hidden by a rounded process covered in thick spiniform hairs; left B1 noticeably longer than right B1 (Figure 21) .....B.spinogibba Defaye, 1998 (A small species collected from shallow water bodies in New Caledonia) (Note: Figure 21 is after Defaye, 1998).

Left Ri large, 2-segmented, extending at least $2 / 3$ distance along inner edge of left Rel.

19. Outer spine left Re2 (= basal portion left Re claw) large, extending to distal extremity of left Re2 (see arrow Figure 22) or at least $2 / 3$ distance from point of insertion to distal extremity of Re2 B. opaqua Fairbridge, 1945

Outer spine left Re2 (= basal portion left Re claw) small, extending only about half distance from point of insertion to distal extremity of Re2 (see arrow Figure 23). B. symmetrica Sars, 1908

20. Left Ri thumb-like (typically 2-segmented), at least twice as long as basal width, extending about 0.3 times distance along inner edge of left Rel (see arrow Figure 24) (large body size; length both sexes $>2.5 \mathrm{~mm}$ ) B.major Searle, 1938
Left Ri vestigial (1 sub-circular segment largely obscured between inner distal corner of left B2 and inner proximal corner of left Re1), not extending along inner edge of left Re1 (see small dotted circles in Figures 25, 27-28) (small or medium body size; length both sexes $<2.5 \mathrm{~mm}$ ).

21. Right Re claw recurved (initially turned inwards, then turned outwards towards extremity) (see arrows Figure 25). B. saycei Sars, 1908

Right Re claw not recurved (continuously curved inwards from proximal attachment to extremity).. 22

22. Left B2 with large, complex (bearing c. 6 small teeth and a small terminal cone-like process) projection at inner distal corner, extending c. 0.5 times distance along inner edge of left Rel (Figure 26). B. tanea Chapman, 1973

Left B2 with small, simple projection at inner distal corner, extending no more than 0.25 times distance along inner edge of left Rel. 23

23. Mean ratio (length right $\mathrm{Ri1}) /($ length right $\mathrm{Ri} 2$ plus length right Ri3) less than 2.5 (Figure 27). B. propinqua propinqua Sars, 1904

Mean ratio (length right Ri1)/ (length right Ri2 plus length right Ri3) greater than 2.5 (Figure 28). B. propinqua longisetosa Smith, 1909

\section{ACKNOWLEDGEMENTS}

We thank the Martu (Tarlka Matuwa Piarku Aboriginal Corporation) for accepting the honour of naming this new species, and to Hamish Morgan and Stephen van Leeuwen for valued assistance in this process. We are grateful to Jane McRae for specimen illustrations (3A-B, 4B-D) and are indebted to Russell Shiel and the staff of Adelaide Microscopy (Angus Netting and Lyn Waterhouse) for providing, and assisting with, the SEM work and images. Acknowledgement and thanks go to Ian Keally, Jennifer Jackson and Julie Futter for advice on site selection and field assistance during the survey work and to Rebecca Coppen for technical support in the laboratory. We also thank Adrian Pinder, Juliet Wege, Bart Huntley and David Cale for providing assistance with components of the manuscript. Finally we thank the two reviewers for their valued comments on the manuscript. Funding of this work was provided by the WA Department of Biodiversity, Conservation and Attractions (Science and Conservation, and Goldfields Region). 


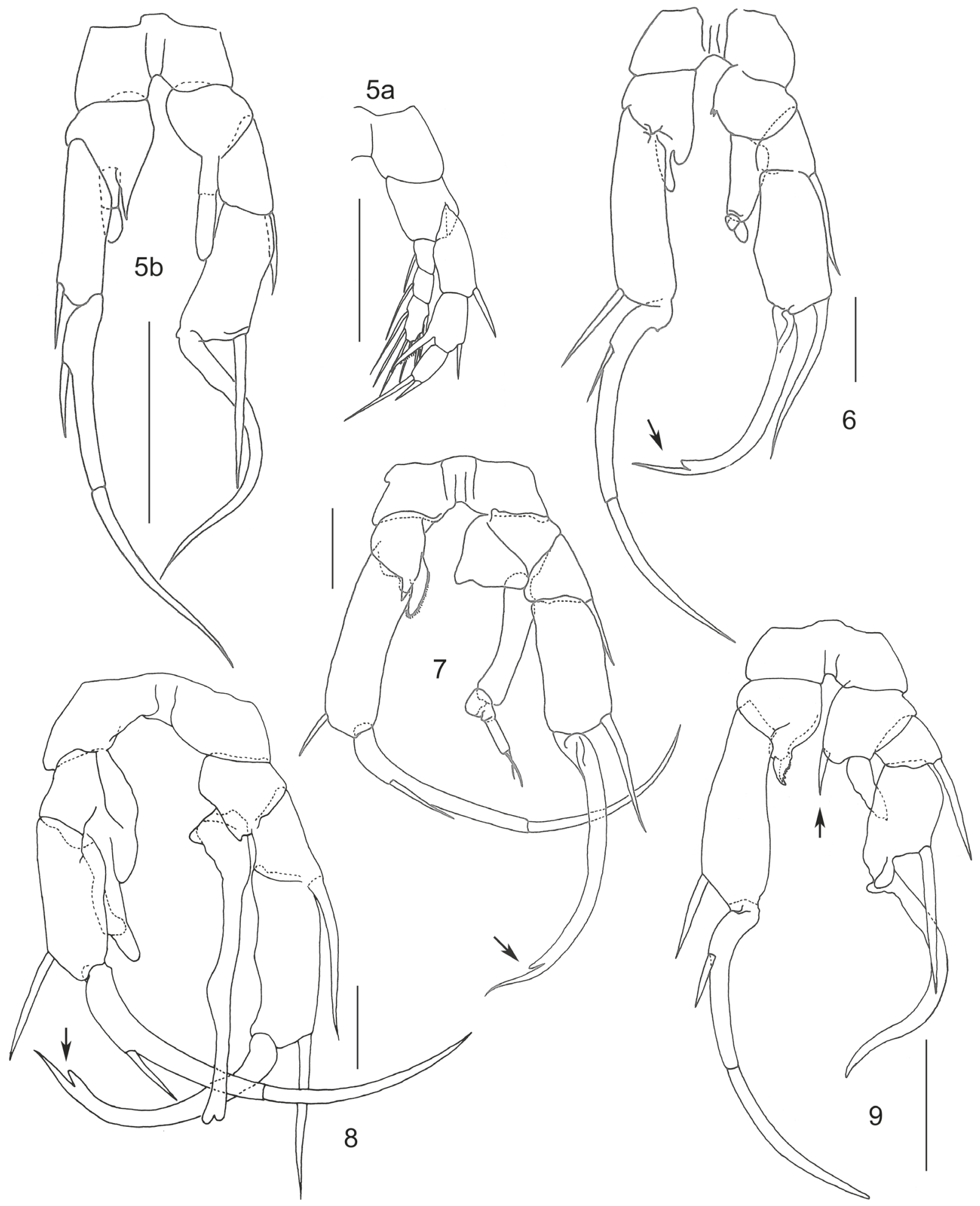

FIGURES 5-9 Boeckella fifth legs (posterior aspect); 5A, B. minuta female right fifth leg; 5B, B. minuta male fifth legs; 6 , B. shieli male fifth legs; 7, B. geniculata male fifth legs; $8, B$. pseudochelae male fifth legs; 9 , B. rubra male fifth legs. Scale $=0.1 \mathrm{~mm}$. 


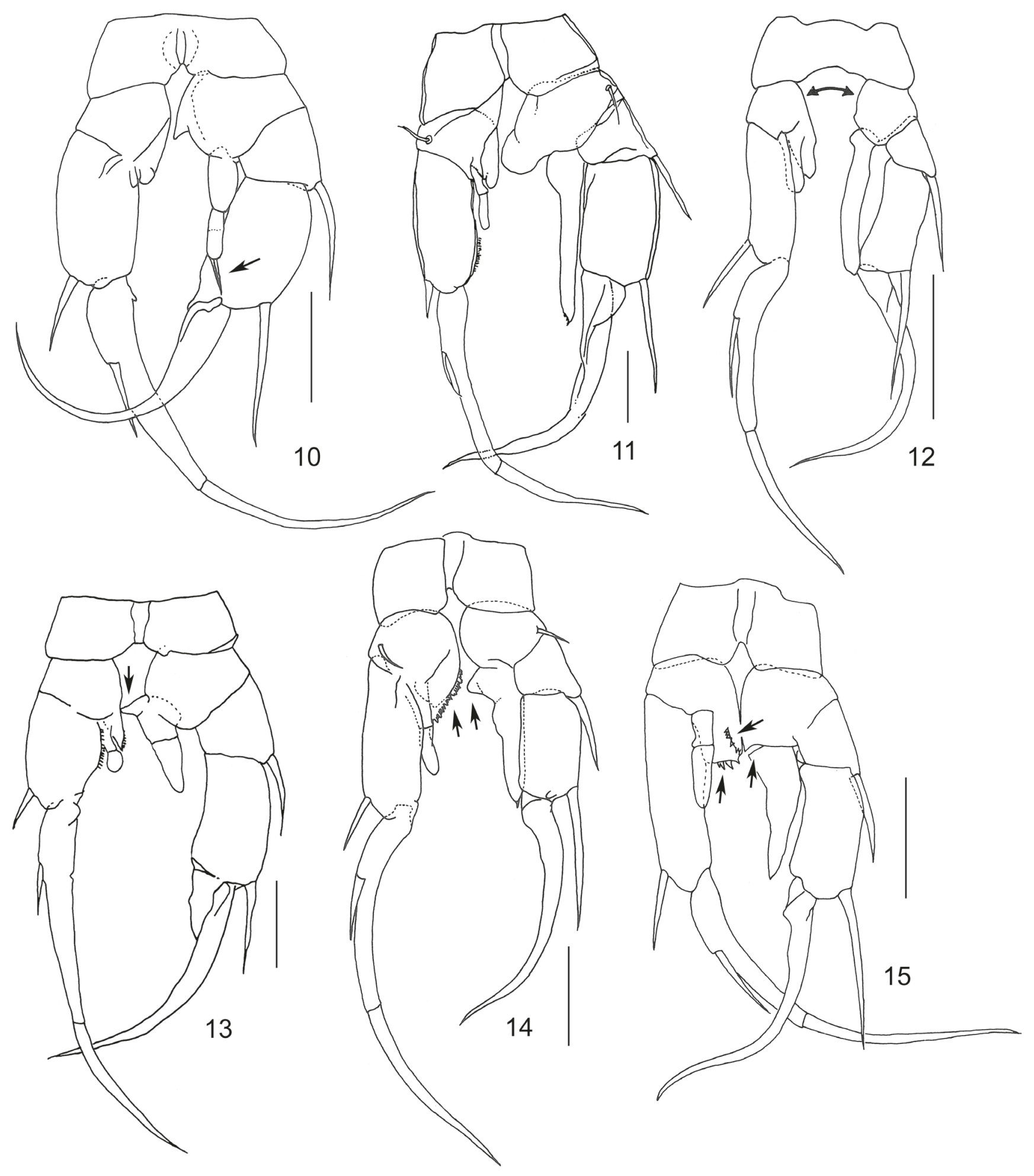

FIGURES 10-15 Boeckella male fifth legs (posterior aspect); 10, B. bispinosa; 11, B. pilkililli sp. nov; 12, B. dilatata; 13, B. timmsi; 14, B. triarticulata; 15, B. fluvialis. Scale $=0.1 \mathrm{~mm}$. 

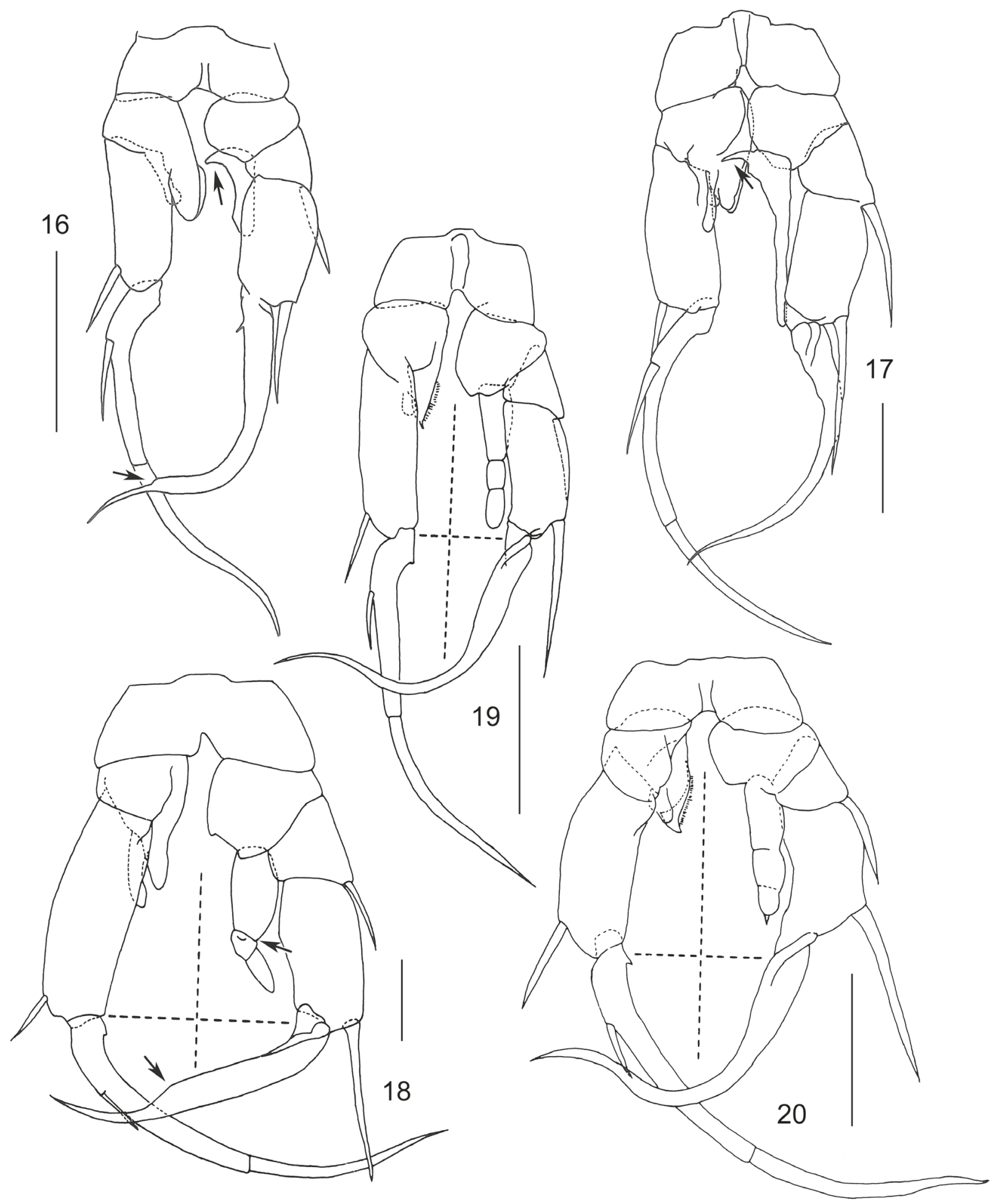

FIGURES 16-20 Boeckella male fifth legs (posterior aspect); 16, B. hamata; 17, B. robusta; 18, B. nyoraensis; 19, B. delicata; 20, B. montana. Scale $=0.1 \mathrm{~mm}$. 

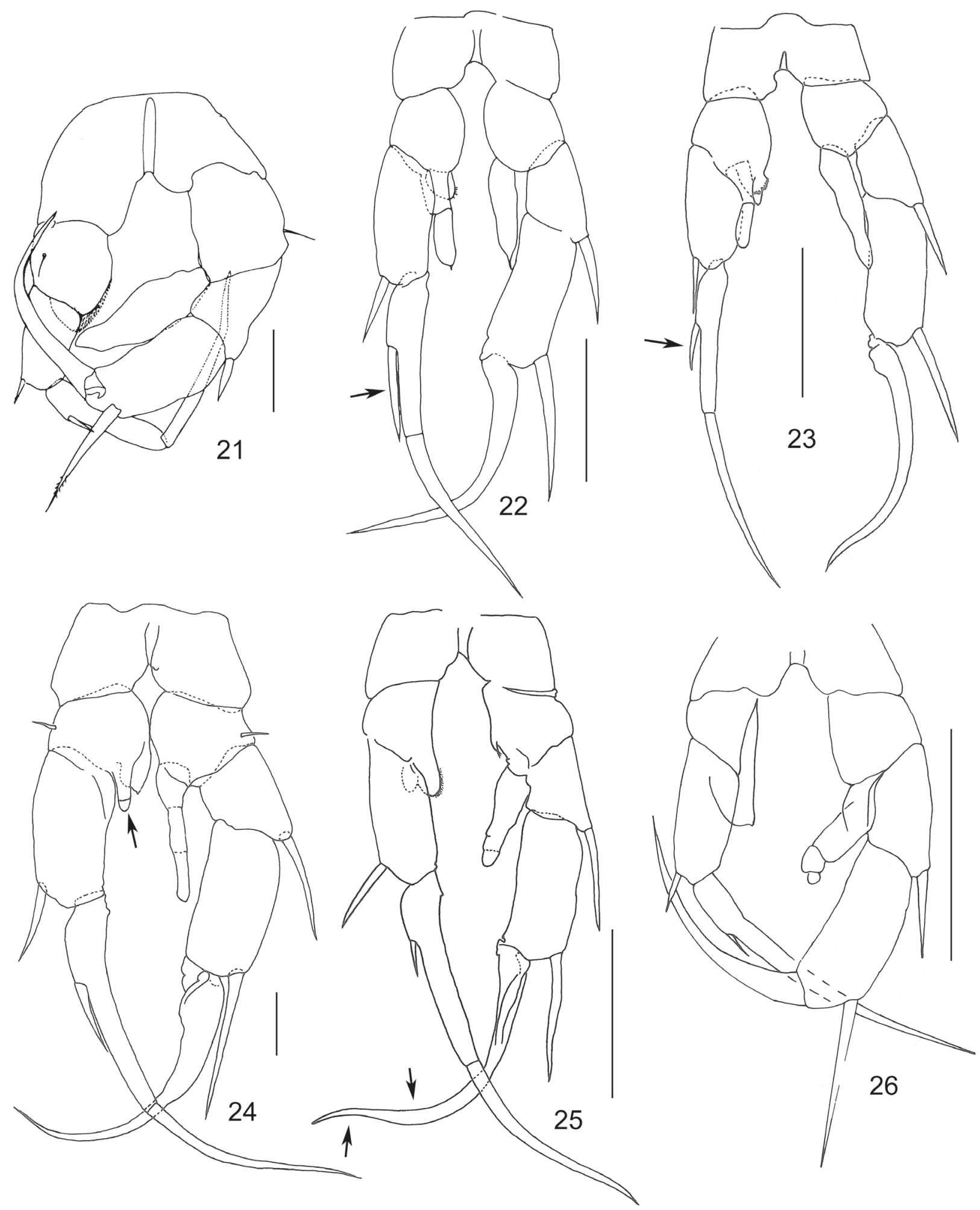

FIGURES 21-26 Boeckella male fifth legs (posterior aspect); 21, B. spinogibba; 22, B. opaqua; 23, B. symmetrica; 24, B. major, 25, B. saycei; 26, B. tanea. Scale: $21=0.05 \mathrm{~mm}, 22-26=0.1 \mathrm{~mm}$ 


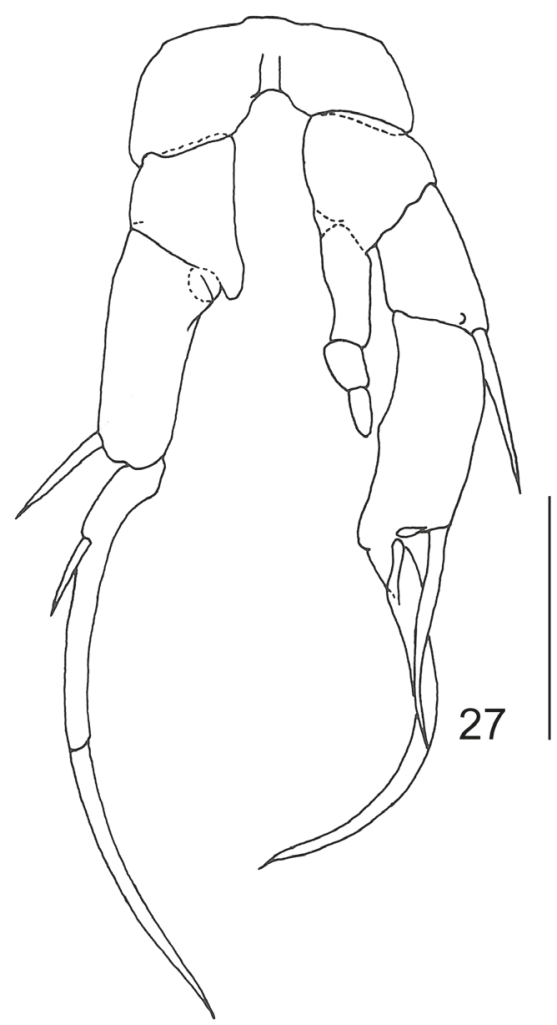

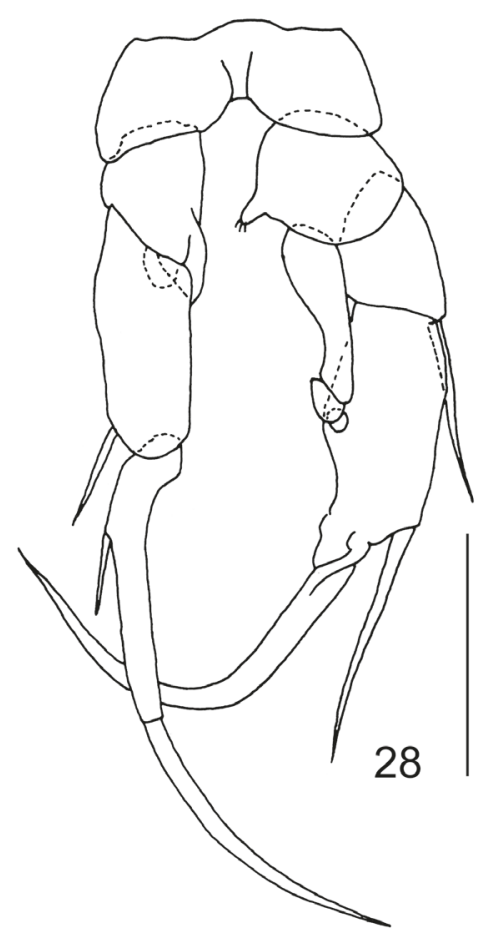

FIGURES 27-28 Boeckella male fifth legs (posterior aspect); 27, B. propinqua propinqua; 28, B. propinqua longisetosa. Scale $=0.1 \mathrm{~mm}$.

\section{REFERENCES}

Australian Government (2012). Interim Biogeographic Regionalisation of Australia v7. Available at http://www. environment.gov.au/land/nrs/science/ibra\#ibra [Accessed 10 January 2017].

Bayly, I.A.E. (1964). A revision of the Australasian species of the freshwater genera Boeckella and Hemiboeckella (Copepoda: Calanoida). Australian Journal of Marine and Freshwater Research 15: 180-238.

Bayly, I.A.E. (1978). Variation in sexual dimorphism in nonmarine calanoid copepods and its ecological significance. Limnology and Oceanography 23: 1224-1228.

Bayly, I.A.E. (1982). The invertebrate fauna and ecology of temporary pools on granite outcrops in southern Western Australia. Australian Journal of Marine and Freshwater Research 33: 599-606.

Bayly, I.A.E. (1985). A new species of Boeckella (Copepoda: Calanoida from Western Australia and comments on two other congeners. Records of the West Australian Museum 12: 79-84.

Bayly, I.A.E. (1992). The non-marine Centropagidae (Copepoda: Calanoida) of the world (pp. 1-30). In: Guides to the identification of the microinvertebrates of the continental waters of the world, No. 2. SPB Academic Publishing, The Hague.
Bayly, I.A.E. (1998). New species of Calamoecia and Boeckella (freshwater Copepoda: Calanoida) from Western Australia and Queensland. Journal of the Royal Society of Western Australia 81: 177-182.

Bayly, I.A.E. (1999) Review of how indigenous people managed for water in desert regions of Australia. Journal of the Royal Society of Western Australia 82: 17-25.

Bayly, I.A.E. and Boxshall, G.A. (2009). An all-conquering ecological journey: from the sea, calanoid copepods mastered brackish, fresh, athalassic saline waters. Hydrobiologia 630: 39-47.

Defaye, D. (1998). Description of the first Boeckella (Copepoda, Calanoida, Centropagidae) from New Caledonia. Crustaceana 71: 686-699.

Giles, E. (1889) Australia twice traversed: the romance of exploration, being a narrative compiled from the journals of five exploring expeditions into and through central South Australia and Western Australia from 1872 to 1876. Volumes I \& II. Sampson Low, Marston, Searle \& Rivington: London.

Green, J.D., Shiel, R.J. and Littler, R.A. (1999). Boeckella major (Copepoda: Calanoida): a predator in Australian ephemeral pools. Archiv für Hydrobiologie 145: 181-196.

Halse, S.A. and McRae, J.M. (2001). Calamoecia trilobata n sp (Copepoda: Calanoida) from salt lakes in southwestern Australia. Journal of the Royal Society of Western Australia 84: 5-11. 
Halse, S.A., Shiel, R.J., Storey, A.W., Edward, D.H.D., Lansbury, I., Cale, D.J. and Harvey, M.S. (2000). Aquatic invertebrates and waterbirds of wetlands and rivers of the southern Carnarvon Basin, Western Australia. Records of the Western Australian Museum Supplement 61: 217-265.

Hancock, M.A. and Timms, B.V. (2002). Ecology of four turbid clay pans during a filling-drying cycle in the Paroo, semi-arid Australia. Hydrobiologia 479: 95-107.

Maly, E.J. and Maly, M.P. (1997). Predation, competition, and co-occurrences of Boeckella and Calamoecia (Copepoda: Calanoida) in Western Australia. Hydrobiologia 354: 41-50.

Maly, E.J., Halse, S.A. and Maly, M.P. (1997). Distribution and incidence patterns of Boeckella, Calamoecia, and Hemiboeckella (Copepoda: Calanoida) in Western Australia. Marine and Freshwater Research 48: 615-621.

Mortimer, N., Campbell, H.J., Tulloch, A.J., King, P.R., Stagpoole, V.M., Wood, R.A., Rattenbury, M.S., Sutherland, R., Adam, C.J., Collot, J and Seton, M. (2017). Zealandia: Earth's hidden continent. GSAToday 27(3): 27-35.

Morton, D.W. and Bayly, I.A.E. (1977). Studies on the ecology of some temporary freshwater pools in Victoria with special reference to microcrustaceans. Australian Journal of Marine and Freshwater Research 28: 439-454.

Pinder A.M., Halse, S.A., McRae J.M. and Shiel, R.J. (2004). Aquatic invertebrate assemblages of wetlands and rivers in the wheatbelt region of Western Australia. Records of the Western Australian Museum Supplement 67: 7-37.

Pinder A.M., Halse, S.A., Shiel, R.J. and McRae J.M. (2010). An arid zone awash with diversity: patterns in the distribution of aquatic invertebrates in the Pilbara region of Western Australia. Records of the Western Australian Museum Supplement 78: 205-246.

Quinlan K., Pinder A., Coppen R., Jackson, J. (2016). An opportunistic survey of aquatic invertebrates in the Goldfields region of Western Australia. Conservation Science Western Australia 10(5): 1-21.
Storey, A.W., Halse, S.A. and Shiel, R.J. (1993). Aquatic invertebrate fauna of the Two People's Bay area, southwestern Australia. Journal of the Royal Society of Western Australia 76: 25-32.

Tarlka Matuwa Piarku Aboriginal Corporation (2015). Matuwa and Kurrara Kurrara IPA Country Management Plan. Prepared by Tarlka Matuwa Piarku Aboriginal Corporation and Central Desert Native Title Services, Wiluna, WA.

Timms, B. V. (1968). Ecological studies on the Entomostraca of a Queensland pond with special reference to Boeckella minuta Sars (Copepoda:Calanoida). Proceedings of the Royal Society of Queensland 79: 41-70.

Timms, B. V. (1979). Body proportions in limnetic and littoral copepods. Australian Journal of Marine and Freshwater Research 30: 417-419.

Timms, B.V. (2001). A new species of Calamoecia (Copepoda: Calanoida) from arid Australia, with comments on the calanoid copepods of the Paroo, northwestern Murray-Darling Basin. Memoirs of the Queensland Museum 46(2): 783-790.

Timms, B.V. (2002). Limnology of the claypans of the Paroo, arid-zone Australia. Verhandlungen des Internationalen Verein Limnologie 28: 130-133.

Timms, B.V. and Boulton, A. (2001). Typology of arid-zone floodplain wetlands of the Paroo River, inland Australia and the influence of water regime, turbidity, and salinity on their aquatic invertebrate assemblages. Archiv für Hydrobiologie 153: 1-27.

Williams, W.D. (1979). Notes on the freshwater fauna of north-western Australia, especially the Kimberleys. Records of the Western Australian Museum 7: 213-227.

Williams, W.D. (1985). Biotic adaptations in temporary lentic waters, with special reference to those in semi-arid and arid regions. Hydrobiologia 125: 85-110.

MANUSCRIPT RECEIVED 23 MARCH 2017; ACCEPTED 17 JULY 2017.

APPENDIX Updated alphabetical checklist of Australian and Zealandia species (and subspecies) in the genus Boeckella.

\begin{tabular}{|c|c|c|}
\hline B. bispinosa Bayly, 1967 & B. nyoraensis Searle, 1912 & B. saycei Sars, 1908 \\
\hline B. delicata Percival, 1937 & B. opaqua Fairbridge, 1945 & B. shieli Bayly, 1985 \\
\hline B. dilatata Sars, 1904 & B. pilkililli sp. nov. & B. spinogibba Defaye, 1998 \\
\hline B. fluvialis Henry, 1922 & B. propinqua longisetosa Smith, 1909 & B. symmetrica Sars, 1908 \\
\hline B. geniculata Bayly, 1964 & B. propinqua propinqua Sars, 1904 & B. tanea Chapman, 1973 \\
\hline B. hamata Brehm, 1928 & B. pseudochelae Searle, 1912 & B. timmsi Bayly, 1998 \\
\hline B. major Searle, 1938 & B. robusta robusta Sars, 1896 & B. triarticulata (Thomson, 1883) \\
\hline B. minuta Sars, 1896 & B. robusta maxima Bayly, 1964 & \\
\hline B. montana Bayly, 1964 & B. rubra Smith, 1909 & \\
\hline
\end{tabular}

